\title{
輸入蒙古挙牛二於ケルつへるくりん應 用結核檢查卜其八解剖的病變卜八比較
}

小野 定 志

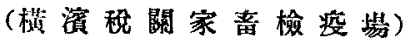

(昭和 5 年 8 月 21 日受附)

目次

\begin{tabular}{|c|c|}
\hline I. 絔富 & IV. 總 \\
\hline II. 檢查要領 & V. 結 \\
\hline
\end{tabular}

I. 緒言

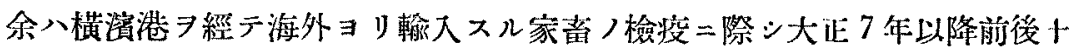
數年間二於テ歐米諸國ヨリ輸入シタ儿貴種/種牞牛、乳用牛或八食用牛二就 キ總數 734 頭ニつベるくりん應用二低儿音牛結核病〉檢查 7 賽施シタリ

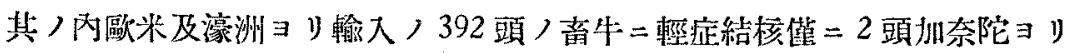
輸入，食用牛 342 頭中疑症 3 頭 $\exists$ 檢出セルノミ然ル二支那青島 $コ$ リ輸入ス 山東省方面ノ食用牛二對シテ八檢疫終了後直二隣接屠場二テ啳敉スルモノカ

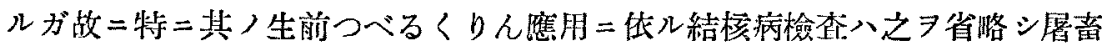
檢查ノ成績 $コ$ 寥照スルコト、七リ然ル二最近 10 简年間 $=15.795$ 頭ノ屠音

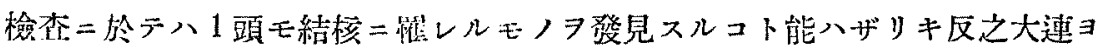
リ輸入サル、食用牛ノ大部分八蒙古地方原產ノ牛野生牛ニシテ常二呼吸器=

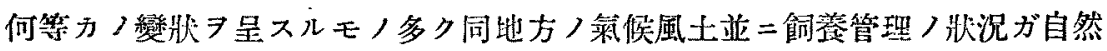
呼吸器系統つ扊患二侵サレ易キ環境ニアルコト推测＝難カラザルモノアリ大

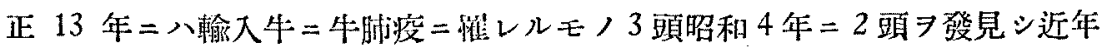

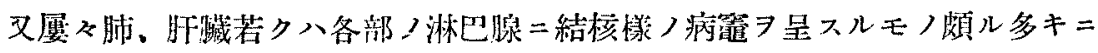
鑑ミ之レカ病理細菌學的檢查/結果孰レモ活動性絬核病簿习有スルコトヨ碓

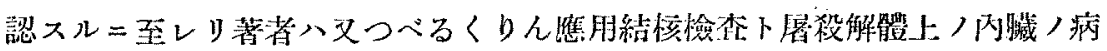




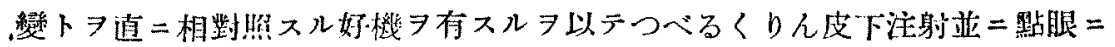

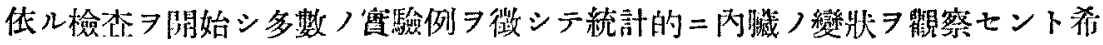
圖シタルモ輸入二消長アリテ目下中絕ノ状沉ナルニヨリ其ノ數谌ダ多カラズ 卜雖モ最近 182 頭ノ檢烃ノ成績 $コ$ 得タレハ茲二之ヨ報告ヒントス

\section{II. 檢 查 要 領}

(a) つべるくりん皮下注射

皮下注射八濃厚つべるくりん 1 二對シ $0.5 \%$ 石炭酸水 9 二稀䠣七ルモノ

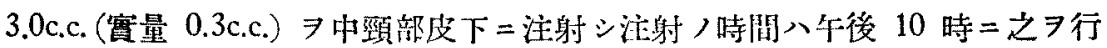

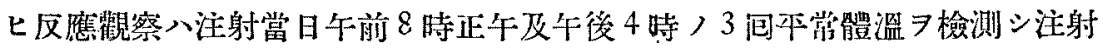

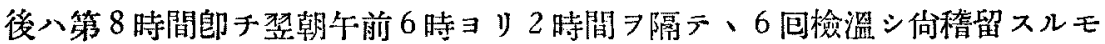
ノ八檢溫 ヨ連續シタリ

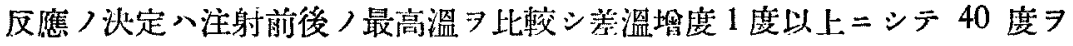
越へ櫡留セルモノヨ陽性反應トシタリ

(b) つべるくりん點眼

點眼ノ方法八特選セ儿圖畫用長悡ノ毛笋 毒淨洗セルモノニ謴厚つべるくりん原液 之 7 結膜囊內 $=$ 插入シ服瞼 7 指間 $=$ テ閉塞保持シ左眼八內㫮 $コ$ 外㫮 $=$ 右眼

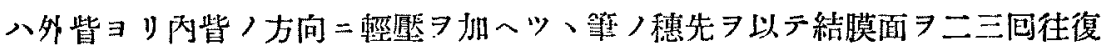

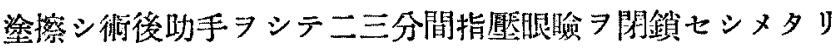

點眼八皮下注射當日午後 5 時ヨリ施行シ反應)診定八點眼前ノ檢枅記錄 参照シ流淡。眼掝、結膜浸潤、充血等持續シ明膫ナルモノフ陽性トセリ而シ テ第 1 包點眼後 48 時間フ隔テ、第 2 回點腿 テナシタリ

(c) 解剖的變常

元來支那ヨリ輸入七ラル、辛牛八皆檢疫終了後八隣接 $/$ 屠場二於テ直二屠 殺セラレ枝闪トシ都方二供給セラル、モノナレ八屠殺後ノ變狀八隣接屠場二 於ケル屠肉檢查，際調查セシモノナリ

III. つべろくりん皮下注射及點眼二㑈ル檢 查成績並二屠音檢査成績卜其／比較

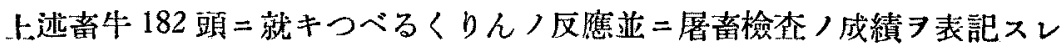


バ次ノ如シ

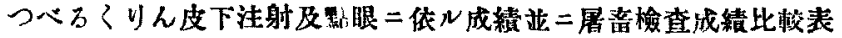

\begin{tabular}{|c|c|c|c|c|c|c|c|c|}
\hline \multirow{2}{*}{ 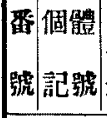 } & \multicolumn{4}{|c|}{ 、友下注射反罴 } & \multicolumn{2}{|l|}{ 應 } & \multicolumn{2}{|l|}{ 屡畕檢查成綪 } \\
\hline & 最高溫 & 差盜 & $\begin{array}{l}\text { 管留 } \\
\text { 時黍 }\end{array}$ & 結 & 症 & $\mid$ 繥| & 病 & |結 \\
\hline I A 25 & 40.3 & $(+) 1.4 \mid$ & 5 & + & 流滨、粘脦漏持續 & + & 咽背淋巴腺結核 & + \\
\hline 21130 & 40.2 & "l 1.2 & 9 & + & 流涋、粘斌膤著明 & + & 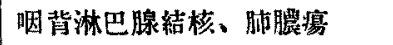 & + \\
\hline 31134 & 40.4 & $" 1.6$ & 9 & + & 流源持績 & + & 氣管枝淋巴腺結核 & + \\
\hline $4 \mid \prime 49$ & 40.3 & $" 1.8$ & 7 & + & 眼煘漏持續 & + & 咽背、氣管枝淋巴腺結核 & + \\
\hline $5 \mid 159$ & 41.1 & $\prime \prime 2.6$ & 9 & + & 差明、流洪持續顯著 & + & 氣管校、縱隔膜淋巴腺結核 & + \\
\hline & 41.2 & 112.7 & 13 & + & 流淡、眼蔵䫛著 & + & $\begin{array}{l}\text { 右肺結核、禾管枝及維隔膜淋 } \\
\text { 巴腺結核 }\end{array}$ & + \\
\hline $7 \mid / 19$ & 41.6 & " 2.7 & 11 & + & 眼倵、流滬極著明 & + & 咽背、氣管枝淋巴腺結核 & + \\
\hline $8 \mid 130$ & 41.8 & " 3.0 & 15 & + & 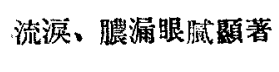 & + & $\begin{array}{l}\text { 栽管枝、䋊隔膜及咽背淋巴腺 } \\
\text { 結 }\end{array}$ & + \\
\hline $9|C \quad 5|$ & 40.9 & 112.2 & 9 & + & $\begin{array}{l}\text { 結膜充血、流淀、眼倵 } \\
\text { 漏 }\end{array}$ & + & 服結核 & + \\
\hline $10 \prime \prime 8$ & 41.8 & $n \quad 3.2$ & 9 & + & 結膜充血、眼㖑持續 & + & 积隔膜淋巴腺結核 & + \\
\hline $11\left|\begin{array}{ll}1 \prime & 9\end{array}\right|$ & 40.5 & $" 2.0$ & 13 & + & 結膜充血、流涺、眼㖑 & + & 咽背及腸間膜淋巴腺結核 & + \\
\hline $12 " 11$ & 41.2 & " 12.6 & 13 & + & $\begin{array}{l}\text { 結膜充皿、流涙、跕淢 } \\
\text { 漏持續 }\end{array}$ & + & 咽背淋巴腺結核 & + \\
\hline $13 \mid \prime 12$ & 41.6 & $\prime \prime 2.9$ & 13 & + & $\begin{array}{l}\text { 結膜充血、流淡眼淢 } \\
\text { 持續 }\end{array}$ & + & 縱隔睲、氣管枝淋巴腺結核 & + \\
\hline $14 \mid / 13$ & 40.2 & $\left|\begin{array}{ll}\prime \prime & 1.4\end{array}\right|$ & 7 & + & $\begin{array}{l}\text { 結膜充血、眼㖑流滬 } \\
\text { 輕度 }\end{array}$ & + & $\begin{array}{l}\text { 秒隔膜、氯管枝淋巴腺及肺結 } \\
\text { 核 }\end{array}$ & + \\
\hline $15 \mid / 18$ & 41.0 & 2.3 & 11 & + & $\begin{array}{l}\text { 眼倵、流滬、結膜充血 } \\
\text { 著明 }\end{array}$ & + & $\begin{array}{l}\text { 氣管枝、縱隔膜、腸間膜淋巴 } \\
\text { 腺、肺及䏕結核 }\end{array}$ & + \\
\hline $16 \mid " 23$ & 41.0 & 2.0 & 11 & + & $\begin{array}{l}\text { 結膜充血、流涙、眼㖑 } \\
\text { 持櫝著明 }\end{array}$ & + & 縱隔膜淋巴腺、脯及肝結核 & + \\
\hline $17 \mid / 27$ & 41.2 & $\begin{array}{ll}\prime \prime & 2.1\end{array} \mid$ & 13 & + & $\begin{array}{l}\text { 結瞙微充血、眼㖑流 } \\
\text { 涙持續 }\end{array}$ & + & 肝結核 & + \\
\hline $18 / 129$ & 41.3 & $1 \prime 2.7$ & 13 & + & $\begin{array}{l}\text { 結膜充血、眼烕定型 } \\
\text { 的症候持續 }\end{array}$ & + & 咽背淋巴腺及脑結核 & $t$ \\
\hline $19 / 111$ & 40.8 & 112.1 & 9 & + & 眼㖑、結膜充血持續 & + & 咽背淋巴腺及瞱䊅核 & + \\
\hline $20 \mathrm{D}$ & 40.0 & " 1.2 & 5 & + & 流涙颀多量 & + & 咽背、晹間膜淋巴腺結核 & t \\
\hline $21 \mid l l$ & 40.5 & $" 1.6$ & 13 & + & 眼淢持續 & + & 咽背、腸間膜淋巴腺結核 & + \\
\hline $22 / \prime 13$ & 40.0 & ll 1.5 & 3 & + & 流泦、眼成 & + & 氣管枝淋巴腺結核 & + \\
\hline $23 / 14$ & 40.6 & $\prime \prime 1.8$ & 9 & + & 結瞙潮紅、流漠、絬戌 & + & $\begin{array}{l}\text { 㸶背、氮管枝、脂間膜淋巴 } \\
\text { 腺及詝結核 }\end{array}$ & + \\
\hline $24 \mid " 19$ & 40.0 & 111.6 & 3 & + & 眼倵、流源 & + & 咽背淋巴腺及脯結核 & $t$ \\
\hline $25 \mid 1 / 27$ & 41.0 & " $\quad 2.7$ & 15 & + & 茬明流滬著明 & + & 紩隔膜、腸間膜淋巴腺結核 & + \\
\hline 26 B 1 & 41.1 & 2.5 & 11 & + & 眼慽、流源、充血著明 & + & 肺包蟲 & - \\
\hline 27 C 39 & 40.4 & 1.7 & 13 & + & 充血、眼胞持櫝 & + & 變狀ナ見ズ & - \\
\hline$|28| \begin{array}{ll}\mathrm{A} & 1\end{array} \mid$ & 40.0 & $\left|\begin{array}{ll}\prime \prime & 1.4\end{array}\right|$ & 5 & $1+1$ & 變化ナシ & - & 肺及氣管枝淋巴腺結核 & + \\
\hline
\end{tabular}




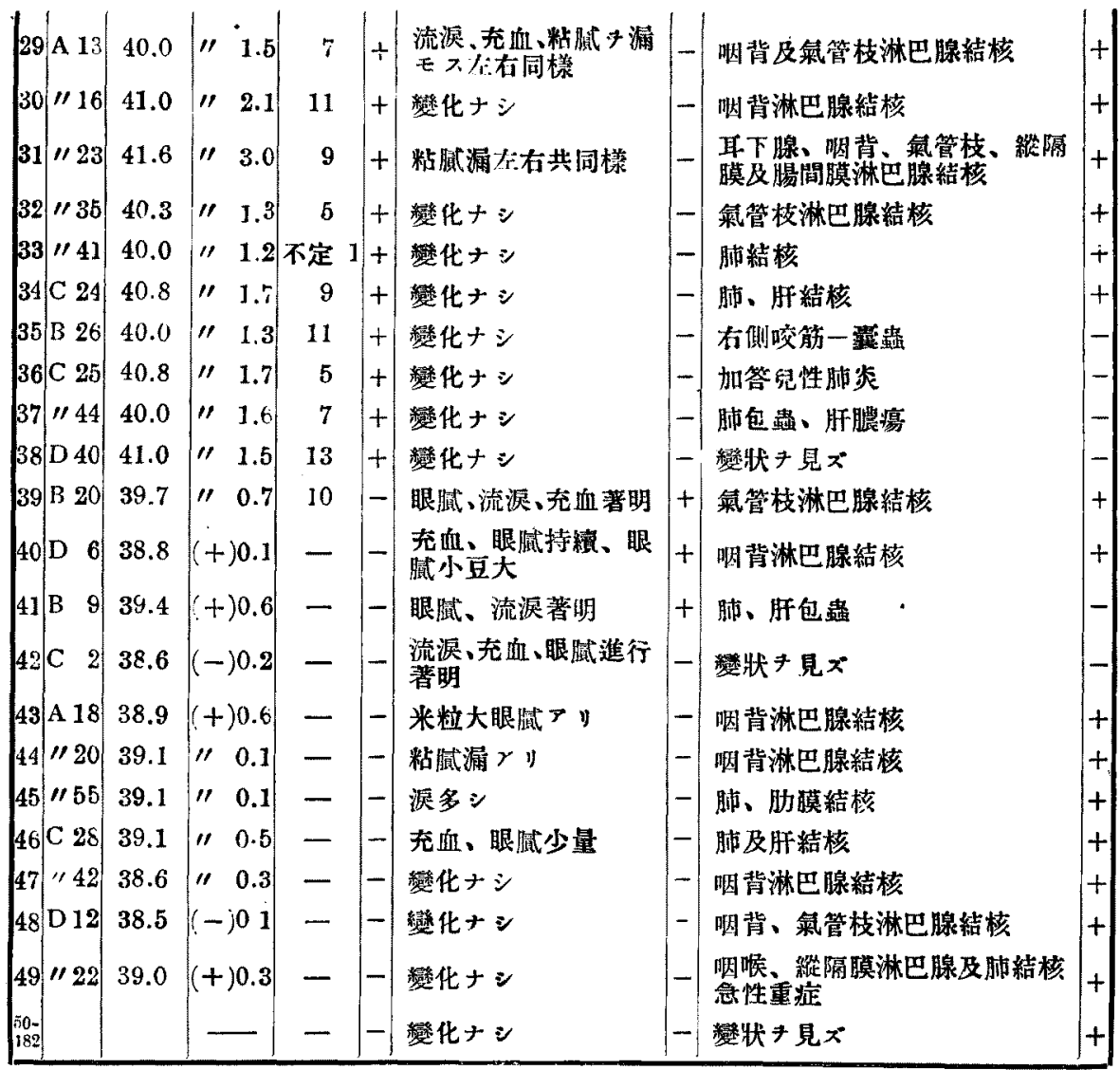

前表ニ於テ見ルガ如ク檢查頭數 182 頭中爇反應陽性ノモノ 38 頭內屠場二

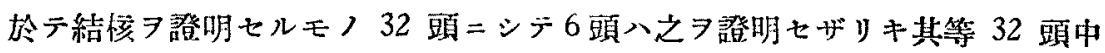
25 頭八點眼反應陽性ニシテ 7 頭ハ陰性ナリ

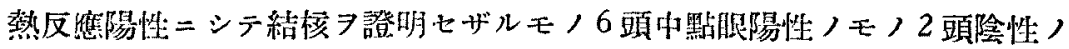
モノ4頭アリ

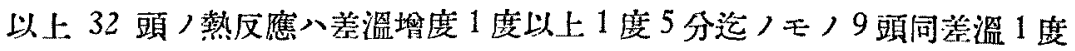
5 分以上 2 度迄ノモ> 8 頭同差淈 2 度以上 3 度ノ增溫アルモ> 15 頭アリ夕 リ又高熱覙留入模樣 7 見ル $=1$ 時閒 1 頭 3 時間 2 頭 5 時間 4 頭 7 時間 3 頭 9 時間 9 頚 11 時間 4 頭 13 時間 7 䁚 15 時間 2 頭ニシテ大多數八 5 時間以上 稳留七り 


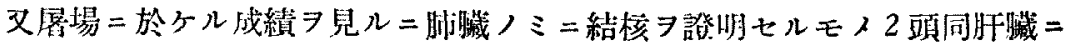

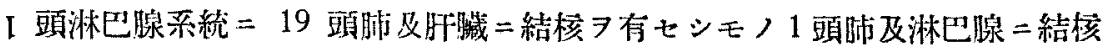

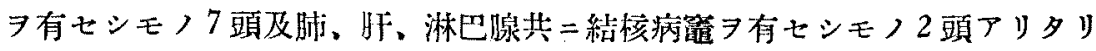

つべるくりん皮下點服兩反應共陽性ニシテ結核タ發見セルモ，25頭 /病 狀八淋巴腺柔結核 15 頭肺結核 1 頚肝結核 1 頭航及淋巴腺結核 6 頭肺折及淋 巴腺結核 2 頭ナリ

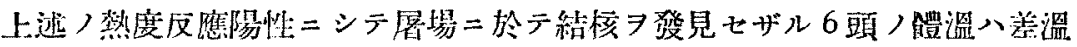
1 度以上 1 度 5 分迄 1 頭 1 度 5 分以上 2 度迄 4 頭及 2 度以上 3 度迄 啫溫了 リシモノ 1 頭ニシテ之等ノ穕放時間八 5 時間 1 頭 7 時間 1 頭 11 時間 2 頭 13 時間 2 頭ニシテ反應比較的明瞭ナリシニ係ラズ屠場ニ於ヶル結果入陰性ナリ $\neq$

熱反應陰性ナリシ 144 頭 ノ內屠場=於テ結核病䇴 7 發見セルモノ9頭アリ 之等ノ內點眼反應陰性ノモノ 7 頭陽性 7 示シタルモノ 2 頭アリ體溫最高 39

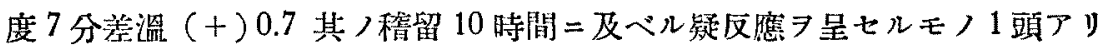
他八全ク皮下注射二對シテハ無反應ナリ

而シテ以上 9 頭ノ屠場二於ヶル成績 7 見ル $=$ 單 $=$ 淋巴腺系統 結核 6 頭肺 肋膜結核 1 頭肺䏜肝結核 1 頭肺

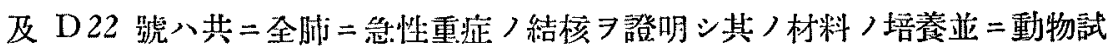
驗二依り强毒ナル結核菌 7 分離シタリ此ノ2 頭八眼反應ノ結果モ陰性ナリキ 檢䄳頭數 182 頭中眼反應陽性ノモ，31 頭 7 檢輸シ其入內屠場二於テ結核 ノ病筐 7 發見七シモノ 27 頭（前述）內熱反應陽性ノモノ25 頭（前述）陰 性ノモノ2 頭?リ結核ヨ發見セザルモノ4 頭アリ內 2 頭八熱反應陽性他ノ 2 頭ハ陰性ナリ

眼反解陽性卜決定セル 32 頭/反隹程度入最モ著明ナリシモノ 12 頭輕度 ノ反應习呈セシモノ 13 頭弱度ノ反應习呈セシモノ6 頭习算セリ

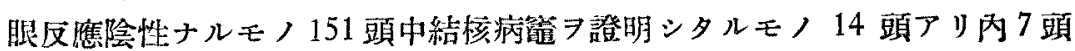
八熱反應陽性残リ 7 頭入陰性ナリ熱反應ノミ陽性ノモノ 11 頭內屠場二於テ 結核 發見セルモノ7頭アリ

之等 14 頭中全ク反應 7 呈セザリシモノ8 頭左右共同一程度ノ變化アリシ 


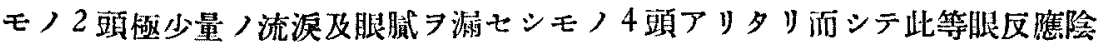
性ニシテ結核病䇴 $フ$ 發見セシモノノ變狀入淋巴腺系統結核 8 頭肺結核 2 頭肺 及淋巴腺結核 2 頭肺及及旰結核 2 頭ナリトス

眼反應陽性ニシテ結核 $フ$ 發見セザリシモノ 4 頭中肺朋二包蟲寄生セシモ，

2 頭及全ク變狀习認メ゙ザリシモノ 2 頭トス

屠畜檢查二於デ結核病筐习證朋シタルモノ 41 頭アリ內肺二病變アリシモ ノ15頭淋巴腺系統=病變アリシモノ 25 頭及肝䑏ニ結核 フ認メタルモノ1 頭ナリ

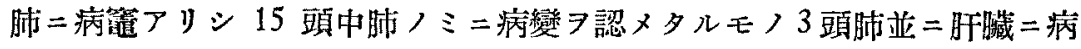
變フ認メタルモノ4 頭朑並二淋巴腺系統二絬核アルモ，8頭內 2 頭八重症 モノナリヌ內 2 頭八腸間膜二結核ヨ併發セリ

淋巴系ニ結核ヨ證明シタル25 頭中凡テ呼吸器系統ノ淋巴腺 $コ$ 犯シ腸間膜 ニモ併發七ルモノ 5 頭アリタリ

總括

以上ノ成績

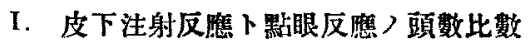

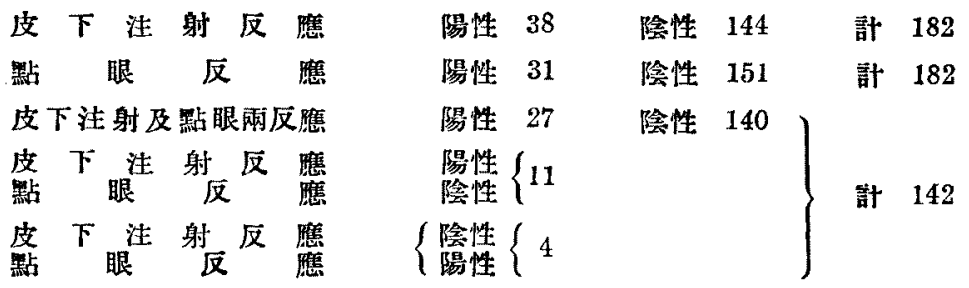

II. 皮下注射反㫿卜屠場二於ラ゙镫明シタル結核症ノ頭數比较

皮下注射反隹

陽性 38

陰性 144

計 182

\section{屠場二於テ證明シタル結核症}

32

9

41

III. 默眼反㮣卜屡昜二於テ證明シタ儿結核症，頭數比較

\begin{tabular}{|c|c|}
\hline 點眼反跑 & \\
\hline 陽性 & 31 \\
\hline 陰性 15 & 51 \\
\hline 計 18 & 182 \\
\hline
\end{tabular}




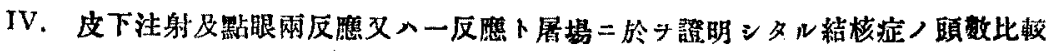

皮下注射及點眼雨反虑陽性 27

闹

點眼反應〉ミ

皮下注射反慧, 三 陰性 4

計

\section{屡埸二於テ短明シタ几結核症}

25

7 (队2 頭、急性重症)

7

2

41

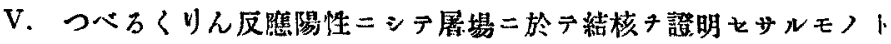

皮下注射及點眼兩反留又心一反應陽性ン頭數比較

つベるくり人反應陽性ニシテ啳

場二於テ結核キ證明もげル頭數

皮下注射及點眼兩反㠊陽性 27

皮下注射反隼了三陽性年 11

點眼反膲

4

計

42

2

2

8

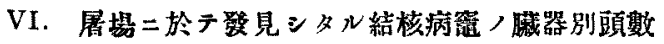

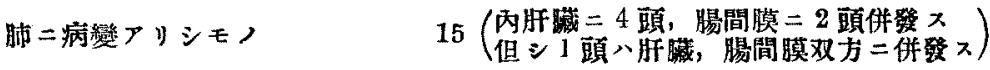

呼吸器系淋巴腺二變狀〉 yシモ>25 (丙腸間膜 $=5$ 頭併發 $ス$ )

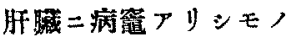

1

計

41

VII. “皮下注射反櫵, 熱型

最高溫 40 度以上ノモノ

最高溫 41 度以上,モノ

22 頭 16 計 38 頭

差溫 1 度以上ノモ,

差溫 2 度以上,モ,

䓔溫 3 度以上ノモ,

$\left.\begin{array}{c}20 \text { 頙 } \\ 31 \prime \prime \\ 3 \prime \prime\end{array}\right\}$ 計 38 頙

慗留 3 時間ヨり 7 時間ノモノ

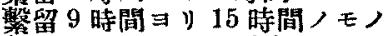

繫留 1 時間ナルモ反複上下シタルモ，

$\left.\begin{array}{c}11 \text { 䫓 } \\ 26^{\prime \prime}\end{array}\right\}$ 計 38 頭

VIII. 眼反㗂, 症狀

䡜キ結膜类ノ症候キ呈スルモ，

中等度〉モノ

膿漏性結膜桨〉庭候キ呈スルモノ

$\left.\begin{array}{c}5 \text { 䫓 } \\ 11^{\prime \prime} \\ 11 \prime \prime\end{array}\right\}$ 計 31 頭

結論

（1）蒙古產ノ鐱入牛 182 䫒中つべるくりん皮下注射 $=ョ$ リ熱反隹

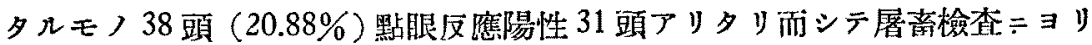
結核二䍜レルモノ 41 頭 $(22.53 \%)$ フ證明シタリ 


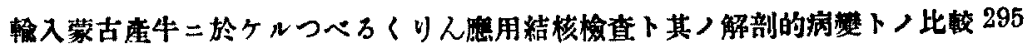

（2）畜屠检查: $ン$ 發見セル 41 頭ノ結核牛中つぺるくりん皮下注射 $=$ ヨリ陽性反碓 $\exists$ 呈七ルモ> 32 頭同點眼反應陽性ノモノ27頭フリ熱並二點眼 兩反應陽性ニテ三者一致セルモノ25 頭 $(13.73 \%)$ ナリトス

（3）つベるくりん皮下注射卜點眼反應卜ノ病牛)發見率八皮下注射法有 利ニシテ且明確ナリキ

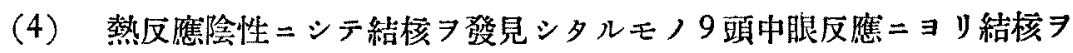
發見シタルモノ2 頭アリ故ニつべるくりん點眼法 7 併用スルコトニヨリ熱反 應ノ缺陷 $习$ 相當償ヒ得ルコト明ナリ

（5）蒙古牛二對スルつべるくりん熟反應入本溫 $コ$ リ度以上 3 度〉增溫 ヨ示シ反隹熱ノ稳留入 3 時間以上 15 時間 $=$ 及ベリ

（6）眼反隹八結膜潮紅、流沃、眼淢ノ持續スル程度 7 普通トスルモ亦結 膜充血、浸㵎、着明、流淡、濃漏性腿倵等顯著ノ反應 二及ベリ

(7) 結核ノ病變 7 登明シタル 41 頭中多クハ呼吸器系統 7 犯シ肺 $=$ 變狀 ヨ見タルモノ 15 頭、消化器系統 $=$ 併破シタルモノ 10 頭內肝臟 4 頭、晹間膜 淋巴腺 6 頭アリ外二肝臟ノミニ發シタルモノ1頭アリタリ

（8）解剖的變常〉著シキモノニシテ却テつべるくりん兩反應㓌性ナルモ ノテリシハつベるくりん應用上注意 7 要スル點ナリトス

\section{A COMPARISON OF TUBERCULIN TESTS WITH ANATOMICAL CHANGES IN MONGOLIAN CATTLE IMPORTED FROM DAIREN, CHINA}

\section{Sadashi Ono}

(From the Laboratory of Animal Quarantine Station, Imperial Customs, Yokohama, Japan)

(Received for publication August 21, 1930.)

For 12 years, 1918 to 1929 , the author has carried himself 
upon the tuberculous inspection in Yokohama for cattle imported from foreign countries, the number amounting to 734 head.

Of 392 head imported from Europe, America and Australia, there were two cases suffered slightly from tuberculosis, while four cases only were suspected among 342 head imported from Canada.

The result of meat inspection of beef cattle imported from Tsingtau, numbering $\mathbf{1 7 . 5 7 5}$ head, revealed no cases of tuberculosis.

On the contrary, the author found out many lung disturbances in the beef cattle imported from Mongolia through Dairen, China, as he detected in 19233 cases, in 19292 cases of bovine pleuropneumonia and several cases of tuberculosis.

The comparison was tried lately between the results of ophthalmic and subcutaneous tuberculin tests and anatomical changes, the number of animals examined amounting to 182 head (see the following table.)

The experiment has been done under following conditions.

(1) Subcutaneous tuberculin test.

Dosis of tuberculin used hypodermically was 3 c.c. consisting of 9 parts of $0.5 \%$ carbolic acid and 1 part of $\mathrm{Koch}^{\prime} \mathrm{s}$ old tuberculin. A rise of temperature of $40^{\circ}$ or above and an increase of at least $1^{\circ}$ above the previous maximum recorded temperatere have been regarded as a positive reaction.

(2) Ophthalmic tuberculin test.

Dap two or three times the surface of conjunctiva with writing brush keeping about 0.3 c.c. of tuderculin. A positive reaction consists in the appearance of a pronounced conjunctivitis.

(3) Anatomical change.

The animals were slaughtered and examined macroscopically in the slaughter-house.

\section{Summary.}

(1) Of 182 head of the cattle imported from Mongolia:

38 cases $(20.88 \%)$ showed the positive reaction in hydpodermic tuberculin test,

31 cases $(17.58 \%)$ showed the positive reaction in ophthalmic tuberculin test, and in

41 cases $(22.53 \%)$ tuberculous herds were demonstrated on 


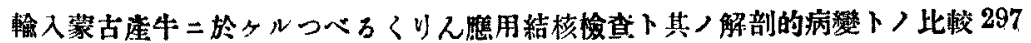

\begin{tabular}{|c|c|c|c|c|c|c|c|c|c|}
\hline en & 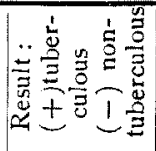 & \pm & \pm & \pm & \pm & \pm & \pm & \pm & \pm \\
\hline 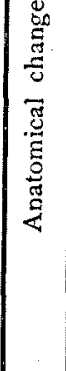 & 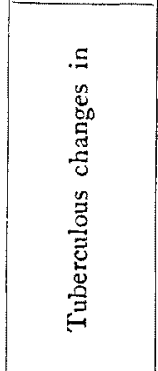 & 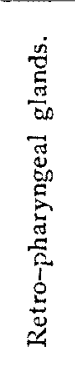 & 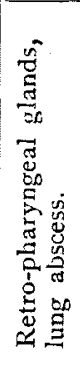 & 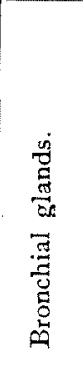 & 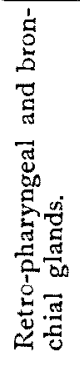 & 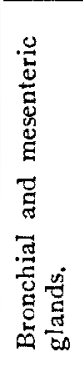 & 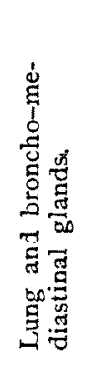 & 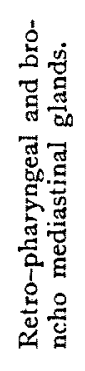 & 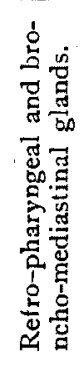 \\
\hline & 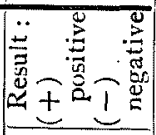 & \pm & \pm & \pm & \pm & $\stackrel{I}{ \pm}$ & \pm & \pm & \pm \\
\hline 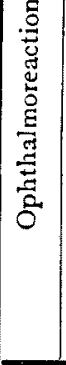 & 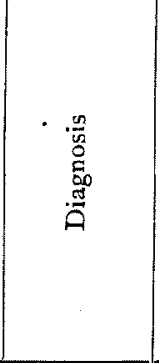 & 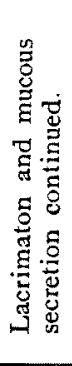 & 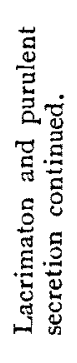 & 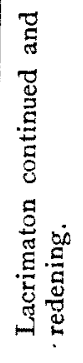 & 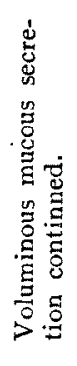 & 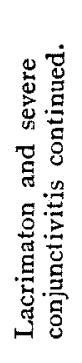 & 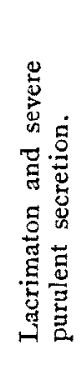 & 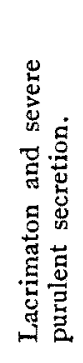 & 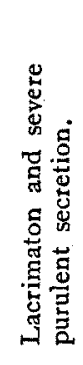 \\
\hline \multirow{4}{*}{ 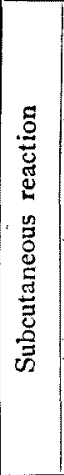 } & 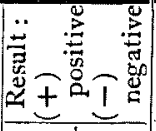 & \pm & \pm & \pm & \pm & \pm & \pm & \pm & \pm \\
\hline & 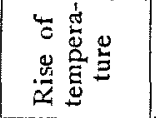 & ج: & $\stackrel{\circ}{\stackrel{\leftrightarrow}{\longrightarrow}}$ & $\begin{array}{l}\stackrel{\circ}{\circ} \\
\stackrel{\circ}{-1}\end{array}$ & $\stackrel{\circ}{\stackrel{\infty}{\sim}}$ & $\begin{array}{l}0 \\
c \\
o i\end{array}$ & $\underset{\text { oi }}{\stackrel{\circ}{2}}$ & $\begin{array}{l}\text { i- } \\
-i\end{array}$ & $\stackrel{\circ}{\circ}$ \\
\hline & 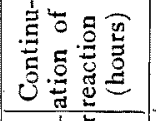 & to & $\sigma$ & $\infty$ & $\sim$ & $\sigma$ & $\stackrel{m}{\sim}$ & $\bar{\nabla}$ & 占 \\
\hline & 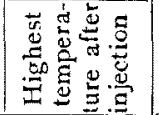 & $\begin{array}{l}\stackrel{\circ}{\infty} \\
\stackrel{8}{\circ}\end{array}$ & $\begin{array}{l}\stackrel{\circ}{9} \\
\stackrel{\circ}{+}\end{array}$ & $\stackrel{\circ}{\stackrel{4}{*}}$ & $\begin{array}{l}\text { in } \\
\text { gn }\end{array}$ & $\frac{0}{F}$ & $\stackrel{\circ}{\sharp}$ & $\frac{8}{\dot{\pi}}$ & $\begin{array}{l}\stackrel{0}{\infty} \\
\stackrel{+}{*}\end{array}$ \\
\hline & 心ే & $\begin{array}{l}\stackrel{5}{4} \\
4\end{array}$ & $\underset{\infty}{\stackrel{8}{4}}$ & 范 & $\underset{\sharp}{\stackrel{O}{*}}$ & $\begin{array}{l}8 \\
i \\
4\end{array}$ & $\begin{array}{l}a \\
\theta\end{array}$ & $\frac{\theta}{\oplus}$ & $\ddot{D}$ \\
\hline & 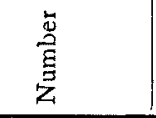 & $\rightarrow$ & 0.9 & $\infty$ & $\nabla$ & 10 & $\infty$ & $r$ & $\infty$ \\
\hline
\end{tabular}


小野 定 志

\begin{tabular}{|c|c|c|c|c|c|c|c|c|c|}
\hline \pm & \pm & \pm & \pm & \pm & \pm & \pm & \pm & \pm & \pm \\
\hline 䓫 & 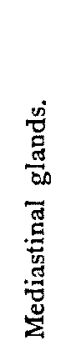 & 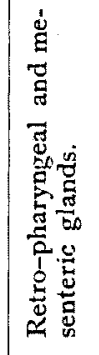 & 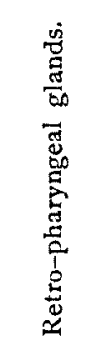 & 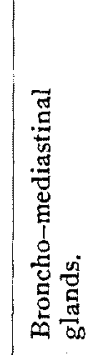 & 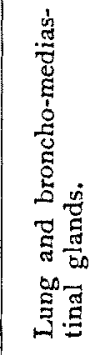 & 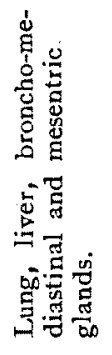 & 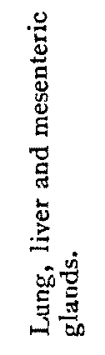 & $\stackrel{\dot{\Xi}}{\stackrel{\Xi}{\vec{I}}}$ & 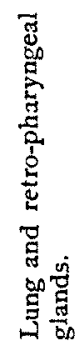 \\
\hline \pm & \pm & 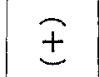 & \pm & \pm & $t$ & \pm & \pm & $\stackrel{f}{ \pm}$ & \pm \\
\hline 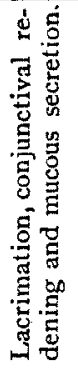 & 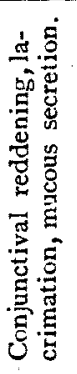 & 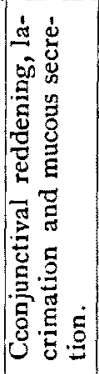 & 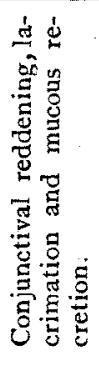 & 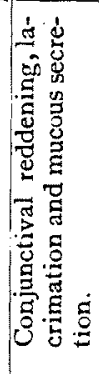 & 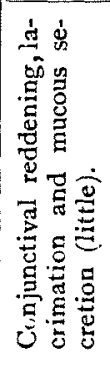 & 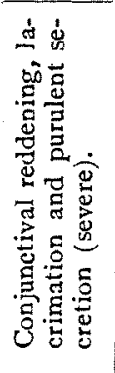 & 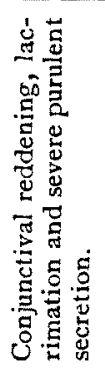 & 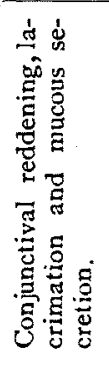 & 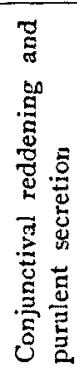 \\
\hline \pm & \pm & \pm & \pm & \pm & \pm & \pm & \pm & \pm & \pm \\
\hline$\stackrel{\circ}{\circ}$ & 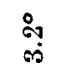 & $\stackrel{\circ}{\stackrel{0}{0}}$ & $\begin{array}{l}\stackrel{0}{\circ} \\
-i\end{array}$ & $\begin{array}{l}\stackrel{8}{S} \\
\text { ai }\end{array}$ & 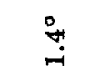 & $\begin{array}{l}\stackrel{\circ}{\circ} \\
\stackrel{\leftrightarrow}{*}\end{array}$ & $\begin{array}{l}\stackrel{0}{0} \\
\text { oi }\end{array}$ & $\stackrel{\circ}{-1}$ & $\begin{array}{l}0 \\
\stackrel{0}{0}\end{array}$ \\
\hline 0 & $\infty$ & $\stackrel{9}{\sim}$ & $\stackrel{90}{\rightarrow}$ & $\cong$ & $t-$ & $\Rightarrow$ & $\Rightarrow$ & $=$ & $\cong$ \\
\hline $\begin{array}{l}\stackrel{\circ}{\circ} \\
\stackrel{8}{*}\end{array}$ & $\begin{array}{l}\stackrel{0}{\infty} \\
\stackrel{\infty}{-1} \\
\stackrel{-1}{7}\end{array}$ & $\begin{array}{l}\stackrel{\circ}{\circ} \\
\stackrel{0}{\circ}\end{array}$ & $\begin{array}{l}\stackrel{8}{G} \\
\stackrel{7}{+}\end{array}$ & 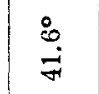 & 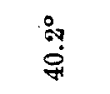 & $\begin{array}{l}8 \\
\dot{7}\end{array}$ & $\stackrel{\circ}{\circ}$ & $\stackrel{\stackrel{\sim}{*}}{\sharp}$ & 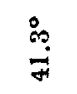 \\
\hline U & $\begin{array}{l}\infty \\
0\end{array}$ & $\begin{array}{l}0 \\
0\end{array}$ & $\overrightarrow{0}$ & $\stackrel{9}{0}$ & $\stackrel{\infty}{0}$ & $\frac{\infty}{0}$ & 芯 & 弪 & $\begin{array}{l}\mathscr{g} \\
0 \\
0\end{array}$ \\
\hline 0 & 운 & $\exists$ & $\stackrel{0}{-9}$ & $\stackrel{2}{2}$ & $\exists$ &. & $\stackrel{\circ}{\sim}$ & $\approx$ & $\stackrel{\infty}{\sim}$ \\
\hline
\end{tabular}




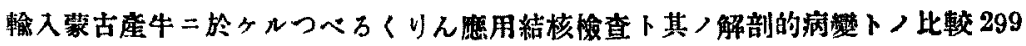

\begin{tabular}{|c|c|c|c|c|c|c|c|c|c|c|}
\hline \pm & \pm & \pm & \pm & \pm & \pm & \pm & I & I & ક & \pm \\
\hline 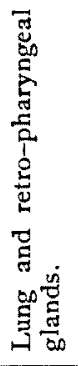 & 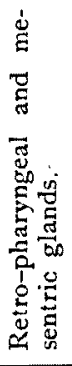 & 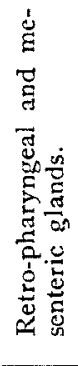 & 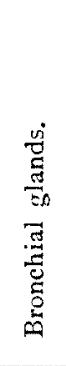 & 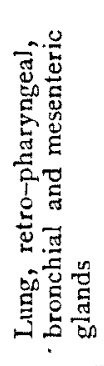 & 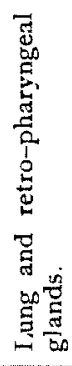 & 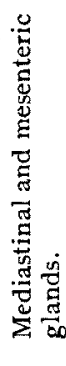 & 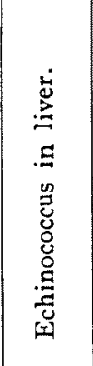 & 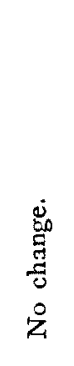 & 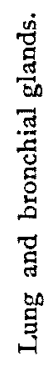 & 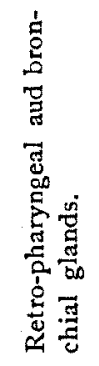 \\
\hline \pm & \pm & \pm & \pm & \pm & \pm & \pm & \pm & \pm & I & I \\
\hline 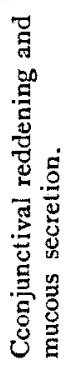 & 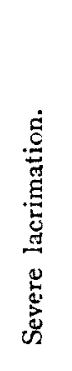 & 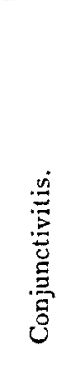 & 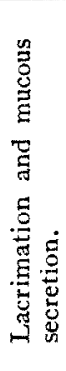 & 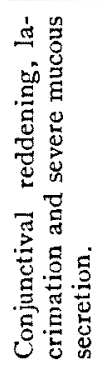 & 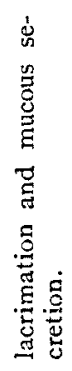 & 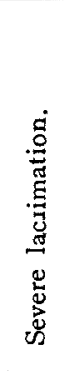 & 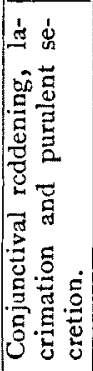 & 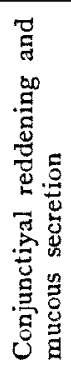 & 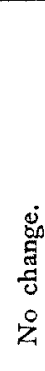 & 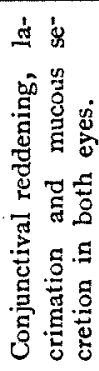 \\
\hline \pm & \pm & \pm & \pm & \pm & \pm & \pm & \pm & \pm & ક & \pm \\
\hline$\frac{0}{a j}$ & $\stackrel{\circ}{\stackrel{\circ}{\prime \prime}}$ & - $\stackrel{0}{\circ}$ & $\stackrel{\circ}{\stackrel{0}{-}}$ & $\stackrel{\circ}{\stackrel{\infty}{-}}$ & $\stackrel{\circ}{\circ} \stackrel{0}{\circ}$ & $\begin{array}{l}i \\
o i\end{array}$ & $\stackrel{i}{i s}_{i j}$ & $\stackrel{0}{\stackrel{5}{5}}$ & $\underset{ }{\stackrel{0}{*}}$ & بم \\
\hline$\infty$ & 0 & 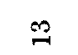 & $n$ & $\theta$ & ח & $\stackrel{20}{\pi}$ & $=$ & $\stackrel{9}{\rightarrow-1}$ & ها & $r$ \\
\hline $\begin{array}{l}\infty \\
\infty \\
0 \\
0\end{array}$ & $\begin{array}{l}\stackrel{8}{\circ} \\
\stackrel{0}{*}\end{array}$ & $\begin{array}{l}\text { is } \\
\stackrel{9}{4}\end{array}$ & $\begin{array}{l}\stackrel{\circ}{\circ} \\
\stackrel{8}{*}\end{array}$ & $\begin{array}{l}: \\
\stackrel{0}{*}\end{array}$ & $\begin{array}{l}\stackrel{8}{0} \\
\dot{H}\end{array}$ & $\begin{array}{l}\circ \\
\text { 업 }\end{array}$ & $\frac{0}{\dddot{3}}$ & 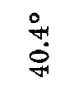 & $\begin{array}{l}\stackrel{0}{\circ} \\
\stackrel{8}{*}\end{array}$ & $\begin{array}{l}\stackrel{\circ}{\circ} \\
\stackrel{\circ}{*}\end{array}$ \\
\hline $\begin{array}{l}\overrightarrow{4} \\
0\end{array}$ & $\begin{array}{l}\infty \\
\oplus\end{array}$ & $\infty$ & $\stackrel{\circ}{\circ}$ & $\frac{\Delta}{a}$ & $\frac{9}{A}$ & $\stackrel{\hat{A}}{A}$ & $\vec{r}$ & $\begin{array}{l}\text { g } \\
0 \\
0\end{array}$ & 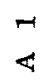 & $\stackrel{\infty}{\square}$ \\
\hline$\stackrel{\theta}{\sim}$ & \&્ఠ & $\overline{\mathrm{N}}$ & 脸 & 89 & 嵀 & ब9? & $\stackrel{\circ}{9}$ & 太ิ & $\stackrel{\infty}{\infty}$ & : \\
\hline
\end{tabular}




\begin{tabular}{|c|c|c|c|c|c|c|c|c|c|c|}
\hline \pm & \pm & \pm & \pm & 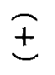 & I & I & I & I & \pm & \pm \\
\hline 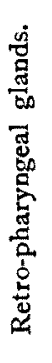 & 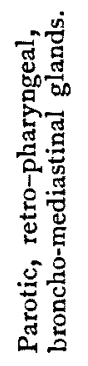 & 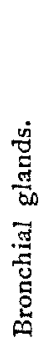 & 宙 & 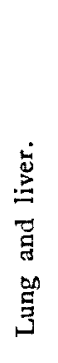 & 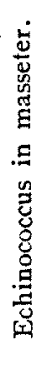 & 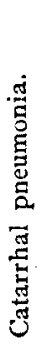 & 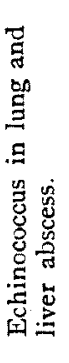 & 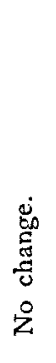 & 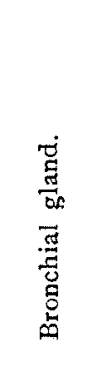 & 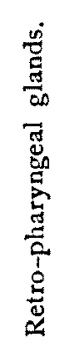 \\
\hline$I$ & $\mathfrak{I}$ & I & I & I & I & 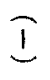 & I & 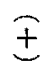 & \pm & \pm \\
\hline 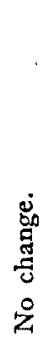 & 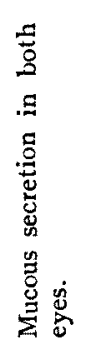 & 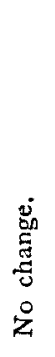 & 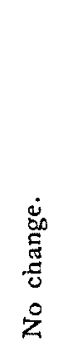 & 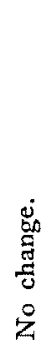 & 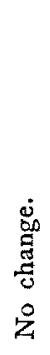 & 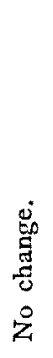 & 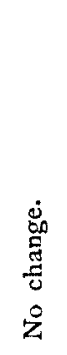 & 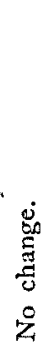 & 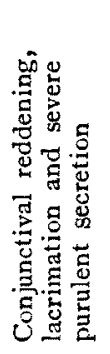 & 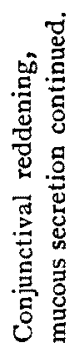 \\
\hline \pm & \pm & \pm & I & \pm & \pm & \pm & \pm & I & 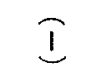 & I \\
\hline ơ & $\dot{O}_{8}$ & ڤ̊ & $\stackrel{\circ}{\stackrel{9}{-}}$ & $\stackrel{\circ}{\beth}$ & $\stackrel{0}{\infty}$ & $\stackrel{g}{\stackrel{2}{\sim}}$ & . & بs & $\stackrel{ }{\circ}$ & \\
\hline$\exists$ & $\infty$ & 10 & $\frac{\vec{b}}{\sigma} . \stackrel{\Xi}{\Xi}$ & $\infty$ & $\Rightarrow$ & 10 & I & 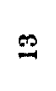 & 음 & \\
\hline$\stackrel{\circ}{\stackrel{0}{0}}$ & $\stackrel{\circ}{\stackrel{-}{-1}}$ & $\begin{array}{l}8 \\
0 \\
0\end{array}$ & $\begin{array}{l}\stackrel{8}{0} \\
\dot{8}\end{array}$ & $\begin{array}{l}0 \\
\infty \\
\dot{\gamma}\end{array}$ & $\begin{array}{l}\stackrel{\circ}{0} \\
\stackrel{0}{*}\end{array}$ & $\begin{array}{l}\stackrel{0}{\infty} \\
\stackrel{0}{0} \\
\stackrel{+}{1}\end{array}$ & $\begin{array}{l}\stackrel{8}{0} \\
\dot{\theta}\end{array}$ & $\stackrel{8}{\not}$ & $\begin{array}{l}\stackrel{0}{1} \\
\stackrel{8}{\circ}\end{array}$ & $\begin{array}{l}0 \\
\infty \\
\infty \\
\infty \\
\infty\end{array}$ \\
\hline$\stackrel{\oplus}{\leftrightarrow}$ & $\begin{array}{l}\stackrel{9}{\leftrightarrow} \\
\longleftrightarrow\end{array}$ & $\begin{array}{l}10 \\
\stackrel{\infty}{\infty}\end{array}$ & $\underset{7}{4}$ & $\begin{array}{l}\vec{S} \\
0\end{array}$ & $\begin{array}{l}\text { \&ै } \\
\text { m }\end{array}$ & $\begin{array}{l}19 \\
\text { G }\end{array}$ & $\vec{j}$ & $\stackrel{9}{\stackrel{9}{9}}$ & $\begin{array}{l}\stackrel{G}{A} \\
\infty\end{array}$ & $\begin{array}{l}\infty \\
\rho\end{array}$ \\
\hline is & ๓ & 今े & $\stackrel{8}{0}$ & ఉొ & 品 & $\stackrel{9}{\circ}$ & to & $\stackrel{\infty}{\infty}$ & $\stackrel{\rho}{\circ}$ & 연 \\
\hline
\end{tabular}




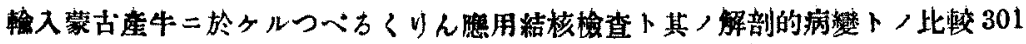

\begin{tabular}{|c|c|c|c|c|c|c|c|c|c|}
\hline I & I & \pm & \pm & $\mp$ & \pm & \pm & \pm & \pm & I \\
\hline 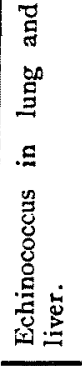 & 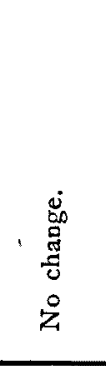 & 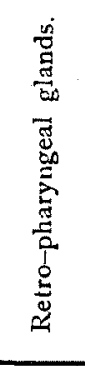 & 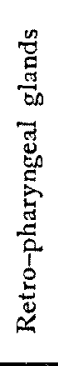 & 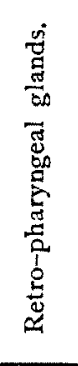 & 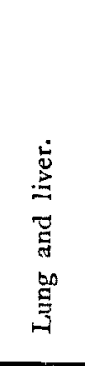 & 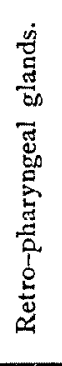 & 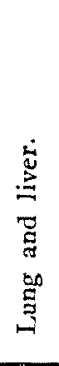 & 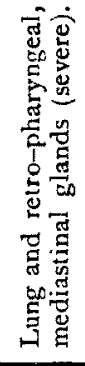 & 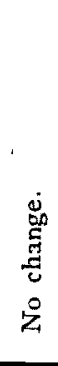 \\
\hline I & \pm & I & I & I & I & I & I & I & $I$ \\
\hline 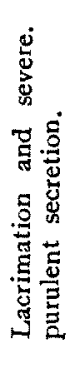 & 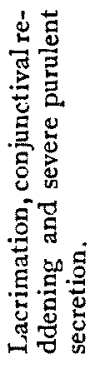 & 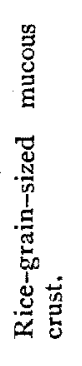 & 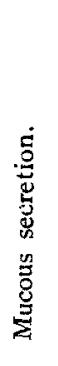 & 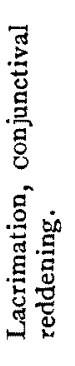 & 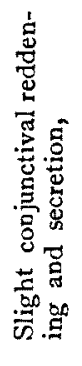 & 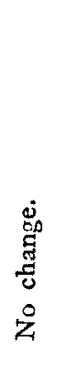 & 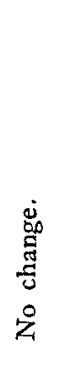 & 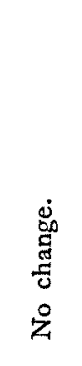 & 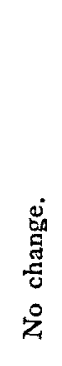 \\
\hline$I$ & I & I & I & I & I & I & I & I & I \\
\hline$\stackrel{\square}{0}$ & 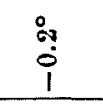 & \begin{tabular}{l}
$\because$ \\
\hdashline
\end{tabular} & $\stackrel{0}{7}$ & $\frac{0}{0}$ & 品 & : & $\begin{array}{l}0 \\
0 \\
1\end{array}$ & $\stackrel{\circ}{0}$ & \\
\hline 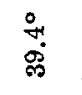 & $\begin{array}{l}\vdots 0 \\
\infty \\
\infty \\
\infty \\
0\end{array}$ & $\begin{array}{l}\stackrel{8}{\infty} \\
\infty \\
\infty\end{array}$ & $\stackrel{\circ}{\circ}$ & $\stackrel{\circ}{\circ}$ & $\stackrel{\circ}{\check{\rho}}$ & $\begin{array}{l}0 \\
\varnothing \\
\infty \\
\infty \\
\infty\end{array}$ & $\begin{array}{l}\text { ip } \\
\text { o } \\
\text { o }\end{array}$ & $\begin{array}{l}\stackrel{0}{0} \\
\text { ه্ল }\end{array}$ & \\
\hline $\begin{array}{l}\infty \\
\infty\end{array}$ & o & $\stackrel{\infty}{<}$ & \begin{tabular}{l}
8 \\
\multirow{4}{4}{}
\end{tabular} & 告 & $\begin{array}{l}\stackrel{\infty}{\Im} \\
\cup\end{array}$ & $\underset{v}{9}$ & $\frac{a}{a}$ & 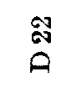 & \\
\hline$F$ & ริ & $\stackrel{m}{\sharp}$ & $\not H$ & $\stackrel{19}{7}$ & $\mathscr{f}$ & 5 & $\stackrel{\infty}{\forall}$ & $\stackrel{9}{7}$ & 息 \\
\hline
\end{tabular}


autopsy.

(2) Among 41 cases showing tuberculous herds 32 cases were positive in hypodermic test, and at the same time, 27 cases positive in ophthalmic test.

25 cases $(13.73 \%)$ were positive in hypodermic and ophthalmic tuberculin tests, and also on autopsy.

(3) The hypodermic tuberculin test was more effective and distinguished than the ophthalmic test in the diagnosis of tuberculosis.

(4) Among 9 cases in which tuberculous herds were demonstrated on autopsy, two cases showed positive ophthalmo-reaction while subcutaneous reaction was negative.

Therefore, it is understood that the ophthalmic test is obviously effective in make up deficiency of the subcutancous test in case the reaction of the latter negative.

(5) In the positive cases of tuberculin test the increase of $1^{\circ}-3^{\circ}$ remained $3-15$ hours.

(6) Among 41 cases with tuberculous herds most of them showed tuberculosis of lymphatic glands of respiratory organs, 15. cases lung tuberculosis and one case liver tuberculosis.

(7) It is necessary to pay attention to some cases of severe tuberculosis showing the negative reaction in both tuberculin tests.

(Author's abstract from his Japanese paper) 